
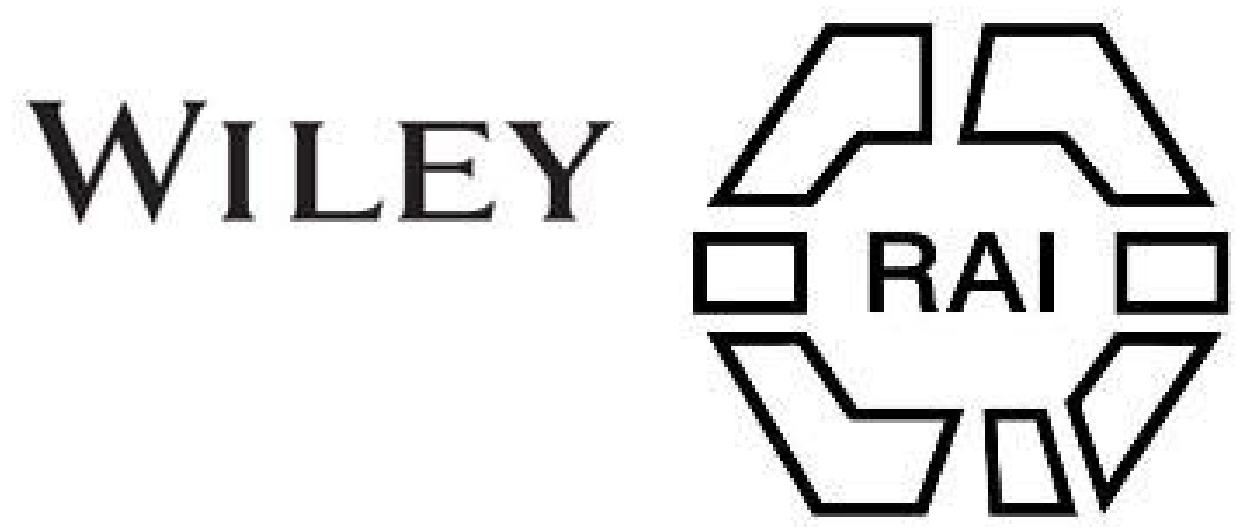

\title{
85. An American View of Totemism.
}

\section{Author(s): N. W. Thomas}

Source: Man, Vol. 2 (1902), pp. 115-118

Published by: Royal Anthropological Institute of Great Britain and Ireland

Stable URL: http://www.jstor.org/stable/2839479

Accessed: 27-06-2016 06:36 UTC

Your use of the JSTOR archive indicates your acceptance of the Terms \& Conditions of Use, available at

http://about.jstor.org/terms

JSTOR is a not-for-profit service that helps scholars, researchers, and students discover, use, and build upon a wide range of content in a trusted digital archive. We use information technology and tools to increase productivity and facilitate new forms of scholarship. For more information about JSTOR, please contact support@jstor.org.

Wiley, Royal Anthropological Institute of Great Britain and Ireland are collaborating with JSTOR to digitize, preserve and extend access to Man 
connection between the kindred and the tribe. In advancing this $I$ do not deny that sometimes a whole local group may be recognised as akin. I have already said that there is a tendency in this direction where the organisation is on the basis of fatherright. What I want to emphasize is that tribe and kindred have no necessary connection either in idea or in fact.

I am much interested in Major Powell's observations on the practices of the Arunta. He rightly describes certain of their ceremonies as analogous to those of the shamanistic societies of America. Two years ago I ventured to call attention to some aspects of this analogy, and expressed the opinion in my Presidential address to the Folklore Society (Folklore, Vol. XI., p. 75) that the Arunta organisation was undergoing a slow transformation from totemism into something more like the societies of British Columbian tribes. There are reasons for believing that the Hopi ceremonial societies have grown out of clan-totemism. Among the peoples of the western deserts of North America, however, the totemistic system has been to a great extent preserved alongside of the ceremonial societies. Among the Arunta, on the other hand, the ceremonial societies seem to be absorbing the totemic organisation. The impression left on Major Powell by the perusal of Dr. Frazer's articles in the Fortnightly Review is that the Arunta groups are not totemistic societies at all but shamanistic societies. This cannot be a definitive judgment because he had not at the time of writing read the book itself. Now that he has done so, as we learn from the postscript, it would be interesting to know whether the impression has been confirmed. Perhaps it has been modified.

The convenient use of the words clan and gens to signify organised groups of cognates and agnates respectively, and the important point of the relation between savage ceremonies and gesture-language, are deserving of careful consideration, but to discuss them here would be to extend this note to an undue length.

\section{E. SIDNEY HARTLAND.}

\section{Totemism.}

Thomas.

\section{An American View of Totemism. $\quad(C f$. MaN, 1902. 75.) Note by $\mathbf{8 5}$
N. W. Thomas, M.A.}

Major Powell's article makes it clear that terms, whose meaning is comparatively well established in Europe, bear a totally different meaning in America. Totemism is, according to him, a system of naming; shamanism is made equivalent to totemism in Dr. Frazer's sense, and a tabu is not a prohibition but an object whose use is prohibited. It is true that the works of Dr. Frazer do not seem to be known in America, and we may perhaps feel legitimate doubts as to whether the perusal of two articles in the Fortnightly Review entitle Major Powell to criticise Dr. Frazer' position. But let that pass.

The mere fact that Major Powell's terminology differs in toto from that in use over shere is not in itself a condemnation of it, nor yet is the fact that he does not understand the European view of totemism an adequate reason for denying the validity of his classification. Totem is originally an Algonquin word, and the Americans are primâ facie the people to whom we should look for an authoritative exposition of totemism as it exists in America. 'The word is used with apparent looseness in Europe; it means, e.g., a system in which the totem is hereditary and which includes exogamy; and it is nevertheless applied to the Arunta system, where neither heredity nor exogamy are found. Dr. Frazer even uses the term of such a purely personal and non-collective relationship as that between a man and his so-called individual totem. This extended use of the term totemism cannot be justified by reference to externals, for in this case we should have to regard as totems the cattle of the Bechuanas, in spite of the fact that the Bechuanas have a clan system, while the whole tribe, irrespective of clan, seems to respect cattle, and that no clan seems to have cattle as its totem. If, therefore, the 
application of the term totemism to all the classes of facts enumerated above is to be justified, it must in the end be on the ground of identical meaning. Dr. Frazer takes this line of argument, but the attempt to include the individual totem is hardly successful ; therefore, until the homogeneity of the three classes of facts above mentioned is established, it would be better to limit the use of the term to one well understood meaning, be this what it may.

Major Powell's view is, it is true, rather a revolution than a reform in nomenclature from the European point of view. The real meaning of totemism being, howerer, still a matter of dispute, we may discuss the American view on its merits. 'The discussion will fall naturally into two parts : in the first place, we must inquire how far the proposed terminology is in itself logical and consistent; we may theu, if necessary, go on to discuss (1) how far the definition covers all the facts which it professes to include, and excludes the remainder, and (2) how far the classification on which it is based is a logical one.

An examination of Major Powell's nomenclature shows that he proposes to use the word totem to mean the following things :-(1) A mark or "clay ;" (2) a body of people organised into exogamous clans ; (3) the name of a body of people; (4) the name of an individual acquired at puberty; (5) the object from which an individual takes his puberty name ; and (6) the object from which a shamanistic society takes its name.

For the sake of uniformity Major Powell might just as well have included in the list of meanings that of the object from which a clan takes its name (or is the omission accidental ?), his arrangement would then have had a certain amount of symmetry ; as it is I am afraid one cannot even say that for it. It is difficult to see the advantage of a system of nomenclature where everything is called by the same name.

If totem originally meant a mark it might be applied to the object which the mark represents ; little or no confusion would arise. But the term cannot be used in scientific terminology as the equivalent of clan without the risk of grave confusion. The meaning "clan" may well have arisen from a European misinterpretation, the mark being mistaken for the clan, because the Amerinds said, "What is your mark?" when they meant "What is your clan?" But it might just as well be maintained that dance in the Bantu languages means "clan" because the equivalent inquiry was, "What do you dance?" Whether this is so or not the double meaning has no place in anthropological terminology.

Major Powell's terminology being what it is, we need hardly go on to discuss how far his definition fulfils its function, nor need we ask how far the facts which he selects for the basis of his definition have been wisely selected. So far as the definition goes, my grandfather may be my totem if I am baptised at fourteen and named after him.

By some extraordinary chance Major Powell has selected as the basis of his theory of totemism precisely those persons or classes of persons to whom, though with certain variations and greater strictness of definition, the European turns in order to study totemism. If totemism is merely a system of naming it is difficult to see on what principle individuals, clans, and bodies of persons to whom are attributed special powers over certain realms of nature and an intimate connection or rapport with the objects which they control, can be grouped together. This course is, as we have seen, justifiable only on the supposition that this special rapport is believed to exist, not only in the case of the last, but also of the other two classes. How far such a rapport is believed to exist in all or any of the classes of facts which Dr. Frazer and, following him, many other European students group together as totemism, and what is the nature of this supposed rapport we may now proceed to inquire.

The central idea of African fetichism is that a spirit, which inhabits temporarily a stone, bone, or other object, becomes for the time being the servant of the possessor of that object. The magical apparatus is sometimes composed of a bag made of the skin [ 116 ] 
of some rare animal which contains parts of various other animals, such as dried monkeys' tails, claws, \&c. Amongst other gifts these bags are believed to confer invulnerability ; sorcerers are said to carry in them the snakes and other noxious animals which they send out to harry their enemies. The animal thus attached to a sorcerer (his familiar) is sometimes regarded as another form of the man himself (it is a world-wide belief that sorcerers can assume the form of any animal they choose), sometimes as a species of evil spirit infesting him, and sometimes as his only messenger. This same diversity of view meets us in the werwolf superstitions. The werwolf is sometimes a transformed man, sometimes a form that can be assumed by man at will; sometımes it is the double and sometimes no more than the messenger of the werman. Bearing in mind that the sorcerer in animal form can harely be distinguished from the werwolf, it seems that the wer-animal was originally the familiar of the werman. (It may be noted in passing that the werwolf is frequently believed to return to the corpse of his victim.)

We may now turn to totemism and consider how far we find analogous beliefs to those just cited. It can hardly escape attention that the medicine bag of the Amerind is the exact analogue of the fetich bag of the negro. It consists of a bag the contents of which are the skin, feathers, or other part of the totem animal. It is carried as an amulet and is believed to confer invulnerability on its owner. The basis of individual totemism seems to be the same as that of fetichism-the association, permanent in this case, of a spirit with a human being whom he possesses or accompanies. This view is borne out by the close relationship between the methods by which the youth obtains his totem and the soreerer his familiar; in each case the dream is the main factor in the operation. So close is this connection betwc en the familiar and the individual totem that Dr. Frazer regards them as identical.

The view that the totem is regarded as an indwelling spirit is also borne out by a fact narrated by the Prinz zu Wied (Reise, II., 190), the importance of which seems to have been overlooked. Many Indians, he states, believed that they had an animal (bison, tortoise, \&c.) in their bodies.

The wide distribution of individual totemism in America makes it possible to explain this as referring to the individual and not the clan totem. But in Australia the individual totem seems to be confined to the medicine man. If, therefore, we find a similar belief in Australia we may infer that, in that continent at any rate, it is a part of the creed of clan totemism. It is stated of the Geawe-Gal tribe (Kamilaroi and Kurnai, p. 280) "apropos of their generic names the Geawe-Gal had a superstition " that every one had within himself an affinity to the spirit of some beast, bird, or " reptile; not that he was sprung from it in any way, but that the spirit which was " in him was akin to that of the creature." This belief suggests that the interpretation suggested for individual totemism can also be applied to clan totemism.

It has been mentioned above that the werwolf is believed to return to look at the body of his victim. In North Queensland when a sorcerer is suspected of having killed a black man, the corpse is placed on a frame aud dust or ashes strewn around, if the track of some animal or bird is found the next morning the totem of the malefactor is inferred from it (Journ. Anthr. Inst., XIII., 191, n. 1). Elsewhere the spirit of the offender was believed to return (loc. cit.), and in New South Wales the flight of a bird over the corpse was believed to indicate the direction in which the enemy would be found (ibid., XIV., 362). These facts seem best interpreted if we suppose that in North Queensland the sorcerer is believed to return to animal form and that the form is that of his totem, for in no other way does it seem possible to identify the man's totem by observing the footsteps. But if a man is believed to have the power of assuming the form of his totem, the totem is prima facie to be explained like the werwolf and the familiar of the sorcerer. The werwolf is, as we have seen, in its origin conceived as a spirit obsessing a man or associated with him as the familiar is associated with the sorcerer. These 
Australian beliefs, therefore, fall into line with those already cited and confirm the suggested view of totemism. On this theory the essential difference between the totem and the fetich is that whereas the human being is regarded as specially associated with an individual fetich or totem, totemism also implies a relation between a human being and a species. How far this distinction is of importance need not be discussed here. It is not difficult to see how totemism, interpreted as I suggest, might, as appears to be the case in South Africa, be transformed into a system of animal worship. These and other questions, such as the applicability of the theory to group totemism, I leave for subsequent consideration.

N. W. THOMAS.

\section{Malay Peninsula.}

Annandale : Robinson.

Anthropological Notes on Sai Kau, a Siamo-Malayan Village in the State of Nawnchik (Tojan). By Nelson Annandale and Herbert $\mathbf{8 6}$ C. Robinson.

The state of Nawnchik (called Tojan by the Malays) is the most northerly of the Siamese Malay States, properly so called, on the east coast of the Malay Peninsula; for in Senggora, though there is a large Malayan element, the Siamese are the dominant as well as the regnant race.

The village of Sai Kau is situated on the interior of Nawnchik, about ten miles from the coast. The population, is roughly speaking, 600, divided almost equally between "Siamese" (Kong Tai) and Malays (Orang Malayu); the two races, if they may be called so, do not live together, but inhabit separate hamlets of about twelve houses each, divided from one another by rice fields. Each hamlet is under a headman, who is called "eh-ban" ; the different "eh-ban" are responsible to a "Tuan eh-ban," who is subordinate to an official called " Toh Blat" or head of the district. The 'Toh Blat, who in the case of Sai Kau is a Malay, is directly under a Siamese magistrate (hakim).

The office of 'Toh Blat is purely gratuitous, no salary or special privileges being attached to it; whilst the jurisdiction is strictly limited to minor offences against the person, which can be punished by placing the offender in the stocks for not more than one day. The duties attached to the office are principally connected with the system of forced labour in vogue.in the Siamese Malay States.

The occupations of the people are almost purely agricultural, consisting of the cultivation of rice, cocoanuts and betel, and the raising of cattle. Both sexes take part in the field work and the women are skilled weavers, there being a loom under nearly every house. The men occasionally search for jungle produce on an adjacent mountain called locally Bukit Besar (the Great Hill).

During a residence of three weeks in the house of the'Toh Blat at this village we had excellent opportunities of observing the people and of collecting their implements, \&c. They made no objection to our taking measurements of their heads and bodies if approached in a judicious manner, and we obtained a series representing nearly a hundred adults, in most cases with specimens of the hair.*

Preliminary analysis of these measurements shows no difference between "Malays" and "Siamese," but there is evidence of the admixture of an element derived from a third, curly-haired race, probably allied to the "Negritoes" of the Peninsula.

As regards the colour of the skin we could observe no special feature in the case of any one type at Sai Kau, the tint depending largely on the relative amount of exposure to the sun. As very little clothing of any kind was worn, on the whole it was fairly uniform, ranging from a yellowish to a dark reddish-brown.

A small proportion of the people had fairly abundant hair on the body.

* In returning the proofs of this paper Mr. Annandale adds that these measurements were taken with proper anthropometrical instruments, and that the instructions given in Anthropological Notes and Queries were followed exactly.-ED. 